\title{
The transition of the world's largest economies to carbon neutrality: areas of potential cooperation with Russia ${ }^{12}$
}

\author{
T. Lanshina, D. Stoyanov, A. Loginova
}

Tatiana Lanshina - PhD in Economics, Senior Researcher at the International Laboratory for Sustainable Development Studies of the Russian Presidential Academy of National Economy and Public Administration (RANEPA); bldg. 1, 82 Prospekt Vernadskogo, Moscow, 119571, Russian Federation; E-mail: lanshina@ranepa.ru

Dmitry Stoyanov - Junior Researcher at the Centre for Economic Modelling of Energy and Environment of the Russian Presidential Academy of National Economy and Public Administration (RANEPA); bldg. 1, 82/1 Prospect Vernadskogo, Moscow, 119571, Russian Federation; E-mail: stoyanov-de@ranepa.ru

Arina Loginova - Student, the Faculty of Foreign Regional Studies and Regional Administration, the Institute of Public Administration and Civil Service, Russian Presidential Academy of National Economy and Public Administration (RANEPA); Junior Researcher at the Centre for Economic Modelling of Energy and Environment of the Russian Presidential Academy of National Economy and Public Administration (RANEPA); Ambassador of SDSN Youth in Russia; bldg. 1, 82/1 Prospect Vernadskogo, Moscow, 119571, Russian Federation; E-mail: loginova-ad@ ranepa.ru

Key words: Sustainable Development Goals (SDGs); Agenda 2030; renewable energy sources (RES), carbon neutrality, net zero emissions.

For citation: Lanshina T., Stoyanov D., Loginova A. (2021) The transition of the world's largest economies to carbon neutrality: areas of potential cooperation with Russia. International Organisations Research Journal, vol.16, no 4, (in English). DOI: https: //doi.org./10.17323/19967845-2021-03-05.

\section{Introduction}

Carbon neutrality has recently attracted a lot of attention from the research community. According to the special IPCC report "Global warming of $1.5^{\circ} \mathrm{C}$ ", human activities have caused an increase of global temperature by $1.0^{\circ} \mathrm{C}$ compared to pre-industrial levels. To minimize climaterelated risks, it is necessary to prevent global warming by more than $1.5^{\circ} \mathrm{C}$ compared to the pre-

\footnotetext{
${ }^{1}$ This article was submitted 07.08.2021

2 The article was written on the basis of the RANEPA state assignment research programme
} 
industrial level. To complete a $1.5^{\circ} \mathrm{C}$ goal, greenhouse gas emissions should peak as quickly as possible, net global anthropogenic emissions should be reduced by $45 \%$ from 2010 levels by 2030 , and a net-zero value should be reached by around 2050. Achieving and maintaining net-zero global anthropogenic emissions can stop anthropogenic global warming [IPCC, 2019].

Carbon neutrality, or net-zero anthropogenic emissions, is usually understood as a situation in which anthropogenic greenhouse gas emissions are balanced by their absorption [Chen, 2021]. Thus, there are two ways to achieve carbon neutrality: (1) reducing emissions by a transition from fossil fuels to renewable energy sources, improving energy efficiency, changing production processes and consumer habits, and (2) absorbing greenhouse gases from the atmosphere, for example, through the protection and planting of forests, soil carbon sequestration, etc. Carbon neutrality can be achieved through a combination of these two options. A drastic reduction in emissions is necessary since currently, the volume of global greenhouse gas emissions is almost four times higher than the volume of their absorption by natural sinks [European Parliament, 2018; C2ES, 2019].

Recently, after numerous pledges and commitments of the world's largest economies to transit to carbon neutrality by the middle of the century, researchers are trying to formulate the measures necessary to achieve this goal [Wan et al., 2021; Safi et al., 2021; Iqbal, 2021; Li et al., 2021]. The transition to net-zero anthropogenic emissions opens up significant opportunities for economic growth. These opportunities extend far beyond the so-called "low-carbon sector". In fact, in the coming decades, the entire global economy will transform. At the same time, demand for greener products will grow rapidly, and countries that take action to develop cleaner technologies, products and processes will be able to create new markets and get significant economic benefits earlier than others [Stern and Valero, 2021].

Russia is not yet among the leaders of the global transition to climate neutrality. Moreover, it is one of the few large economies in the world that has not yet set a goal of achieving zero net emissions by the middle of the century and has not developed appropriate strategic documents. Considering that the decisions on the transition to climate neutrality have already been made or are about to be made by most countries of the world, both with developed and developing economies, Russia is under the threat of losing its export markets and, consequently, under the threat of a large-scale economic crisis. To identify industries that will grow the most in the world's largest economies transitioning to carbon neutrality, the first part of this article analyzes strategic documents of the respective countries. The second part formulates the low-carbon sectoral priorities of the world's largest economies. The third part examines the level of development of the relevant economic sectors in Russia. Finally, in conclusion, the authors develop 
recommendations for transforming the Russian economy and list areas that are promising for propelling international economic cooperation, taking into account the emerging global changes.

\section{Plans of the world's largest economies to achieve climate neutrality}

An increasing number of countries have declared their intention to achieve net-zero emissions by the middle of the century. As of June 2021, 132 countries and the EU have discussed or adopted a climate neutrality goal, of which 90 countries were in the discussion stage, 26 countries included a carbon neutrality goal in their strategic documents, 4 countries considered the possibility of adopting a law that would make the achievement of net-zero emissions mandatory, 10 more countries and the EU have already adopted such a law, and 2 countries (Suriname and Bhutan) have achieved climate neutrality [Energy \& Climate Intelligence Unit, 2021a]. As of March 2021, countries that have made or are discussing a commitment to net-zero emissions accounted for $61 \%$ of global greenhouse gas emissions, $68 \%$ of GDP, and $56 \%$ of the world's population [Energy \& Climate Intelligence Unit, 2021b].

Among the countries in the top 10 in terms of gross domestic product (GDP), calculated at purchasing power parity (PPP), only two countries - India and Russia - have not yet set the timeline for the transition to carbon neutrality (Table 1). Four out of the ten largest economies and the EU have set a legally binding goal of carbon neutrality. Five out of the ten largest economies and the EU have already started to develop plans or programs for such a transition. The absence of a goal for achieving carbon neutrality and a corresponding strategy in Russia creates risks of a worsening economic situation and a decline in living standards in the country in the coming decades. 
Table 1. National plans to achieve carbon neutrality in the TOP-10 economies of the world and the EU

\begin{tabular}{|c|c|c|c|c|c|}
\hline № & Country & $\begin{array}{l}\text { GDP by PPP in } \\
2020, \text { trillion US } \\
\text { dollars }\end{array}$ & $\begin{array}{llr}\text { Timeline } & \text { for } & \text { the } \\
\text { transition } & \text { to } \text { carbon } \\
\text { neutrality } & & \\
\end{array}$ & Carbon neutrality in the law & $\begin{array}{l}\text { Plan or strategy for the carbon } \\
\text { neutrality transition }\end{array}$ \\
\hline $\mathbf{1}$ & China & 24,27 & 2060 & - & - \\
\hline 2 & United States & 20,94 & 2050 & - & $\begin{array}{l}\text { The Biden plan for a clean energy } \\
\text { revolution and environmental } \\
\text { justice }\end{array}$ \\
\hline 3 & India & 8,91 & - & - & - \\
\hline 4 & Japan & 5,33 & 2050 & $\begin{array}{l}\text { The Act on Promotion of Global } \\
\text { Warming Countermeasures }\end{array}$ & $\begin{array}{l}\text { The Green Growth Strategy } \\
\text { through achieving } \\
\text { neutrality by } 2050\end{array}$ \\
\hline 5 & Germany & 4,47 & 2045 & The Climate Change Act & $\begin{array}{l}\text { The Climate Action Programme } \\
2030\end{array}$ \\
\hline 6 & $\begin{array}{l}\text { Russian } \\
\text { Federation }\end{array}$ & 4,13 & - & - & - \\
\hline 7 & Indonesia & 3,30 & 2060 & - & - \\
\hline 8 & Brazil & 3,15 & 2060 & - & - \\
\hline 9 & France & 3,12 & 2050 & $\begin{array}{l}\text { The Energy and Climate Law } \\
\text { (2019) }\end{array}$ & $\begin{array}{l}\text { The National Low-Carbon } \\
\text { Strategy }\end{array}$ \\
\hline \multirow[t]{2}{*}{10} & United Kingdom & 3,02 & 2050 & The Climate Change Act & $\begin{array}{l}\text { The Ten Point Plan for a Green } \\
\text { Industrial Revolution }\end{array}$ \\
\hline & $\mathbf{E U}$ & 19,69 & 2050 & $\begin{array}{l}\text { The European Climate Law } \\
(2021)\end{array}$ & The European Green Deal (2019) \\
\hline
\end{tabular}

Source: Compiled by the authors based on [World Bank, 2021], [Energy \& Climate Intelligence Unit, 2021a], and other open sources. 


\subsection{The European Union}

The European Green Deal, adopted by the European Commission in 2019, sets the EU's goal of transition to climate neutrality by 2050. At the end of 2020, the European Council approved a mandatory EU target for a net domestic reduction in greenhouse gas emissions of at least $55 \%$ by 2030 compared to 1990 [European Council, 2020]. Previously, by 2030, it was planned to reduce emissions by $40 \%$. On June 24, 2021, the European Climate Law was adopted, which legislated the goal of achieving carbon neutrality by 2050 and established the European Scientific Advisory Council on Climate Change, which will provide independent scientific advisory support and publish reports on the realization of the European Climate Law and implementing international obligations of the EU under the Paris Agreement [European Council, 2021].

For a fair transition to a green economy, the European Commission has developed a set of measures related to energy, industry, consumption, infrastructure, transport, agriculture, as well as taxation and provision of benefits. Improving energy efficiency, developing renewable energy sources and phasing out fossil fuels will play a critical role in the implementation of the European Green Deal. Reducing greenhouse gas emissions in the energy system will be of prior importance since the production and use of energy in various sectors accounts for more than $75 \%$ of all greenhouse gas emissions in the EU countries [Eurostat, 2021]. In 2020, solar and wind energy alone produced $19.6 \%$ of EU electricity. The share of coal in electricity generation in the EU fell from $25 \%$ in 2015 to $13 \%$ in 2020 [Ember, 2021]. In the future, RES will become the basis of the entire EU energy sector. An important part of the EU Green Deal is the energy transition in the transport sector, as well as in the heating/cooling sector, in which progress is still significantly slower than in the electricity sector. To achieve the goal of the EU Green Deal, it is necessary to reduce greenhouse gas emissions in the transport sector by $90 \%$ through the modernization of road, rail, water, and air transport. A significant proportion of road freight transport (75\%) should be transferred to rail and inland waterways [European Commission, 2019]. Large-scale electrification of road transport is planned. By 2035, the EU will ban the sale of cars with internal combustion engines (ICE) [European Commission, 2021]. Buildings account for about $40 \%$ of energy consumption in EU countries [European Commission, 2019]. To reduce greenhouse gas emissions from buildings, a large-scale renovation is planned. Energy efficiency renovations will primarily affect the poorest households, schools, and hospitals.

The EU industrial sector accounts for about $20 \%$ of all greenhouse gas emissions. European industrial companies have already begun to shift towards a circular economy, but so far only $12 \%$ of raw materials in the EU are recycled materials [European Commission, 2019]. In May 2021, the European industrial sector received an updated strategy that has three main priorities: environmental friendliness, digitalization, and competitiveness. The most energy-intensive 
industries, such as steel, chemicals and cement production, will modernize first. The strategy provides for a transition to a new business model with the introduction of technologies for the reuse of materials for production, increasing responsibility of producers, sharing of goods and services, and expanding opportunities and participation of consumers. In addition to energyintensive industries, priority will be given to resource-intensive industries such as construction, electronics, textiles, and plastics production. The environmental policy in the field of production will also touch upon the problems of waste generation and disposal, which will require legislative approval of new targets and measures to combat waste generation, including the expansion of the market for secondary raw materials and the use of environmentally friendly primary raw materials. Digital technologies will play an important role in this transition, allowing for optimal use of energy resources, as well as innovative technologies in key industries.

In addition, the EU Green Deal contains plans to solve the problems of ecosystems and biodiversity as well as air pollution. For example, concerning biodiversity, the proposals relate to extending the coverage of protected areas on land and at sea and for restoring damaged ecosystems, including carbon-rich ecosystems [European Commission, 2019].

\subsection{Germany}

Germany's path to carbon neutrality is enshrined in the 2019 Climate Protection Act [Bundesamt für Justiz, 2019]. Germany is one of the few EU countries that have legislated the transition to a carbon neutral economy. In April 2021, Germany's Federal Constitutional Court made a historic decision that the country's key climate law does not detail the goals of reducing greenhouse gas emissions after 2030 and is thus insufficient to rapidly reduce emissions [Bundesverfassungsgericht, 2021]. After that, an updated version of the Climate Protection Act was developed and approved by the German government in May 2021. According to it, by 2030, greenhouse gas emissions should be reduced not by $55 \%$, as previously planned, but by $65 \%$, and by 2040 - by $88 \%$, compared to the 1990 level; climate neutrality must be achieved by 2045 . The Bundestag adopted these amendments on June 24, 2021 [Bundesregierung, 2021a].

To fulfill the objectives of the Climate Protection Act, in 2019 the Climate Action Program 2030 was developed [Bundesregierung, 2019]. A key element of this program is the introduction of a carbon price for the transport and heating sectors from 2021, in addition to the EU emissions trading scheme. The proceeds from this mechanism will be directed to the green sectors of the German economy. The program provides tax incentives to improve energy efficiency in buildings, replace old fossil-fueled central heating systems with new, more environmentally friendly ones, or these that are run on renewable energy sources. By 2030, RES will provide $65 \%$ of the country's electricity needs. In 2020, 50.5\% of all German electricity was produced using RES, including 10.5\% using solar PV energy and 27.0\% using wind energy [Fraunhofer, 2021]. All coal-fired 
power plants in Germany will be closed by 2038. In the transport sector, electrification, the use of railways and public transport will be encouraged. By 2030, the German network of electric charging stations will reach 1 million units. It is also planned to introduce renewable energy sources in industrial processes, develop hydrogen energy, the production of energy storage devices, technologies for storing and using $\mathrm{CO} 2$. In the agricultural and forestry sectors, priority will be given to organic farming, waste reduction, sustainable forest management. Following the amendments to the Climate Protection Act, another program was adopted aimed at achieving Germany's climate neutrality by 2045 - the Immediate Action Program 2022 [Bundesministerium der Finanzen, 2021]. The program will prioritize the reduction of greenhouse gas emissions in the industrial sector (using hydrogen in the steel industry for green steel production, stimulating investment in the chemical industry), energy (energy transition in thermal energy, green hydrogen production), and buildings.

\subsection{France}

On November 8, 2019, France adopted the Energy and Climate Law, which requires a transition to carbon neutrality by 2050 [Legifrance, 2019]. According to the law, climate neutrality will be achieved through more than sixfold reductions in greenhouse gas emissions. The law envisages the closure of the last coal mines by 2022 , a $40 \%$ reduction in fossil fuel consumption by 2030 compared to 2012, a reduction in the share of nuclear energy in the electricity sector to $50 \%$ (currently $70 \%$ ), stimulation of the development of offshore wind energy, covering with solar panels at least $30 \%$ of the roof area of new warehouses, supermarkets and parking lot canopies. Much attention is paid to improving the energy efficiency of buildings, in particular, through mandatory energy audits for residential premises leased or offered for sale, a ban on rent increases for non-energy efficient residential premises, etc.

In 2020, to make France carbon neutral, the National Low-Carbon Strategy [Ministere de la Transition Ecologique, 2020], first adopted in 2015, was revised. According to the document, by 2050 , the French energy sector will be completely carbon-free. Because of the developed nuclear energy sector, the share of fossil fuels in the French electric power sector is already low 9\% in 2019 [IEA, 2021a]. The transport sector, except for domestic air transport, will be completely decarbonized by 2050 through electrification and switching to hydrogen fuel, traffic management, promotion of public transport, etc. It is also planned to significantly increase the energy efficiency of buildings, including through the renovation of 500 thousand houses per year. Emissions from the industrial sector will be reduced by $81 \%$ by 2050 due to the introduction of renewable energy technologies and energy efficiency, the management of raw materials flows, and the introduction of elements of a circular economy, R\&D in the field of low-carbon production processes. Measures are also planned for agriculture and forestry (development of agroecology 
and agroforestry, minimizing the use of nitrogen fertilizers, carbon sequestration in agricultural soils, sustainable forestry, etc.) and the waste management sector (waste reduction, reuse, and recycling).

\subsection{United Kingdom}

The UK passed a law mandating net-zero emissions by 2050 back in 2019, through amendments to the 2008 Climate Change Act [UK Legislation, 2019]. Previously, the Climate Change Act provided for an $80 \%$ reduction in greenhouse gas emissions by 2050 compared to 1990.

In November 2020, British Prime Minister Boris Johnson presented the "The Ten Point Plan for a Green Industrial Revolution" [UK Government, 2021]. The plan aims to rebuild the economy after the pandemic, create 250,000 green jobs by 2030 and accelerate the transition to net-zero emissions. The plan provides for the development of offshore wind energy, the production of low-carbon hydrogen, the development of nuclear energy, the transition to zero-emission transport, the stimulation of green public transport, air and water transport with zero emissions, green construction, the attraction of investments in carbon capture, use and storage, protection of natural ecosystems and fostering green finance and innovation. The UK is already a global leader in offshore wind energy. It is planned to quadruple the capacity of offshore wind farms by 2030.

Over the past 5 years, the UK has practically abandoned coal-fired power generation: in 2015, British coal-fired thermal power plants produced $23 \%$ of all electricity in the country, in 2020 - less than $2 \%$. The transition was mainly due to the rapid development of renewable energy: the share of electricity production from wind and solar energy in the country increased from 14\% in 2015 to $29 \%$ in 2020 [Ember, 2021]. By 2024, the UK will decommission all coal-fired power plants. From 2030, the UK plans to introduce a ban on the sale of new cars with internal combustion engines.

\subsection{United States}

The United States does not yet have a law making the transition to carbon neutrality a legally binding goal, but this goal is already part of some strategic documents. For example, on January 27, 2021, US President Joe Biden signed the Executive Order on Tackling the Climate Crisis at Home and Abroad [The White House, 2021], according to which the climate crisis should be at the center of the US international and national security policy and the US must achieve netzero emissions no later than 2050.

Also, the goal of achieving net-zero greenhouse gas emissions by 2050 is present in US President Joe Biden's plan for a clean energy revolution and environmental justice [Joe Biden, 2020]. The plan called for a $100 \%$ clean energy transition by 2050. On April 1, 2021, Biden presented his plan to renovate infrastructure and industry. According to it, a complete transition to 
clean energy should be carried out by 2035 [Joe Biden, 2021]. Nuclear and renewable energy currently produce $38 \%$ of all electricity in the United States.

The United States has traditionally been a leader in R\&D and innovation. Biden's 2020 plan [Joe Biden, 2020] provides for the creation of the Advanced Research Projects Agency Climate (ARPA-C), a new interdepartmental agency that will focus on research in the following areas: small modular nuclear reactors, cooling and air conditioning using refrigerants, buildings with zero clean energy consumption, hydrogen production from renewable energy sources at competitive prices, obtaining carbon-free industrial heat required for the production of steel, concrete and chemicals, production of carbon-neutral building materials, decarbonization of the food and agricultural sectors, capturing and storing carbon in the soil, capturing carbon dioxide from the exhaust gases of power plants to store it deep underground or use it for industrial purposes. This department will be created by analogy with the Advanced Research Projects Agency-Energy (ARPA-E) and the Defense Advanced Research Projects Agency (DARPA).

In addition to clean energy, US plans for the transition to carbon neutrality include the development of electric transport, improving the energy efficiency of buildings (reducing the carbon footprint of buildings by $50 \%$ by 2035), improving agricultural practices, and introducing low-carbon technologies in the manufacturing sector.

\subsection{Japan}

The first announcement of Japan's intention to move towards carbon neutrality by 2050 was made by Prime Minister Suga Yoshihide in October 2020. Before that, Japan had planned to cut greenhouse gas emissions by $80 \%$ by 2050 . The goal of achieving carbon neutrality was fixed at the legislative level through amendments to the Act on Promotion of Global Warming Countermeasures [MIC, 2021].

In December 2020, Japan presented the Green Growth Strategy through achieving carbon neutrality by 2050 [METI, 2020]. The strategy contains industrial policy measures, and its goal is to achieve positive economic growth while ensuring environmental protection. The document identifies 14 sectors in which transformations are needed and also sets a target for the share of renewable energy sources in electricity production at the level of 50-60\%. The strategy provides for the electrification of industry and transport, the active development of offshore wind energy and energy storage, low-carbon hydrogen fuel, nuclear energy (including safer next-generation reactors), as well as carbon capture, storage, and use technologies (CCUS), due to high Japan's dependence on fossil fuels. In particular, it is planned to take actions in such difficult sectors for decarbonization as water transport, aviation, and cargo transportation. In addition, the strategy involves the introduction of sustainable agricultural, forestry, and fishery practices and the development of a circular economy. The document provides for $R \& D$ with the state (state fund 
with a capital of 2 trillion yen) and private financing, the implementation of demonstration projects, and the commercialization of new low-carbon technologies.

The main source of greenhouse gas emissions in Japan is the electric power sector, which accounts for more than half of all emissions in the country and which is more than $70 \%$ dependent on fossil fuels [Nakano, 2020]. Currently, Japan is implementing its fifth energy baseline plan, adopted in 2018. According to this plan, by 2030 the share of RES in electricity production will be $22-24 \%$, the share of nuclear energy $-20-22 \%$, the share of coal and gas $-63 \%$. In addition, the fifth plan includes targets for energy conservation, hydrogen energy, energy storage, and the implementation of decentralized energy systems. The sixth basic energy plan will be adopted in the summer of 2021. The nuclear energy target is expected to remain the same, while the renewable energy target will almost double to $35-39 \%$ by 2030 , by reducing the use of fossil fuels.

\subsection{China}

China has not yet presented a long-term strategy for achieving net-zero emissions, but in September 2020, at the UN General Assembly, Chinese President Xi Jinping announced his intention to move towards net-zero greenhouse gas emissions by 2060 [FMPRC, 2020]. China accounts for nearly $30 \%$ of the world's total greenhouse gas emissions [C2ES, 2019]. According to the International Energy Agency (IEA), China's greenhouse gas emissions increased by $356 \%$ by 2018 compared to 1990, showing a slight decrease only in the period 2013-2016, after which growth resumed again [IEA, 2021e].

In China, since 1953, the main goals and directions of the country's socio-economic development have been planned for five years. Policy within the 13th Five-Year Plan (2016-2020) was largely determined by the Paris Climate Agreement, which China joined in 2016. The goals of the 13th five-year plan for energy included reducing the share of coal in primary energy consumption to at least $58 \%$ by 2020 , compared to $64 \%$ in 2015 , mainly due to the large-scale development of renewable energy sources. The goal was achieved - by the end of 2020, the value of this indicator was 56.8\% [Reuters, 2021a]. The 13th five-year plan also set a limit on the total capacity of coal-fired power plants at $1,100 \mathrm{GW}$ in 2020 , but this limit was exceeded already in 2019. This suggests that coal will continue to be China's largest source of electricity in the near term.

China's coal policy is driven by both environmental and economic priorities, that is, inefficient use of coal is primarily reduced by closing down old power plants and small coal-fired boilers that combust coal in an inefficient manner. The rest of the coal-fired power plants are equipped with technologies for cleaning coal before combustion. Reducing the use of coal at the household level is also a priority policy area due to the large number of households using coal for heating and domestic needs. 
China, being a leader in the use of fossil fuels, is at the same time a world leader in the field of renewable energy. In 2020, $10 \%$ of Chinese electricity was produced using only solar PV and wind energy [Ember, 2021]. Most of the companies in the top 10 solar PV panels and wind turbines manufacturers are Chinese companies. The share of all renewable energy sources in electricity generation in China is over one quarter.

In March 2021, the Chinese government presented the main provisions of the 14th fiveyear plan (2021-2025). The new plan provides for an increase in the share of non-fossil fuels in the total energy consumption to $20 \%$ by 2025 , an increase of $40 \%$ in the installed capacity of nuclear power plants, and a decrease in the energy intensity of GDP by $13.5 \%$. Compared to China's 13th Five-Year Plan, the new plan does not look ambitious. The new plan also does not contain targets for reducing coal capacities, the possibility of building new coal-fired power plants is allowed, and an increase in the consumption of oil, coal and natural gas is possible. This approach is conservative and insufficient to achieve carbon neutrality by 2060.

\subsection{Countries without strategic documents for the transition to carbon neutrality}

In 2020, Brazil committed to the transition to carbon neutrality by 2060, and in April 2021, President Jair Bolsonaro announced a possible postponement of this deadline to 2050. However, the transition to climate neutrality is still an intention, as it is not enshrined in any strategic documents or plans, and the possibility of postponing the date from 2060 to 2050 was contingent on attracting foreign aid in the amount of $\$ 10$ billion a year to fight with illegal logging of the Amazonian forests [Reuters, 2021b]. Deforestation is the largest source of greenhouse gas emissions in Brazil, due to, among other things, weak government policies to protect forests. In addition, the loss of Brazilian forests has been accelerating: in 2019, more than 1 million hectares of Amazonian forests were destroyed, which is 34\% more than in 2018 and $120 \%$ more than in 2012 [Climate Action Tracker, 2020].

Brazil's energy system is very different from the systems of other major economies due to the significant share of renewables in it - they account for about $45 \%$ of primary energy consumption and more than $80 \%$ of electricity production. The basis of renewable energy in the country is hydropower (over $60 \%$ of all electricity production), as well as biomass and biofuels [IEA, 2021c]. Brazil's latest 10-year energy plan envisages that by 2029, the installed capacity of solar power plants will be $8.4 \mathrm{GW}$, wind power plants - 24.4 GW [Climate Transparency, 2020]. In addition, Brazil is expanding the use of bioethanol and biodiesel in the transport sector, but there are no targets to phase out sales of cars with internal combustion engine vehicles in the country.

In March 2021, the Indonesian government announced its intention to achieve climate neutrality by 2070 , later this date was changed to 2060 . However, this goal is not approved, and 
no strategic documents are planning to achieve it [Climate Home News, 2021]. For Indonesia, the main challenge is the decarbonization of the energy sector, in which coal-fired generation plays a significant role. In addition, Indonesia is the largest exporter of coal by weight. In May 2021, it was decided to stop the construction of new coal-fired power plants. The possibility of phasing out coal-fired generation by 2060 is being considered, given that coal currently provides $60 \%$ of the country's electricity production [IEA, 2021d]. It is also possible to introduce a carbon tax in Indonesia.

For India, the timeline for the transition to climate neutrality is still not determined. This is because a drastic reduction in greenhouse gas emissions could limit access to energy for the most vulnerable groups of the population. The country's rapid economic growth has led to a sharp doubling in energy consumption in 2000-2020. The country's energy balance is based on coal - it provided $44 \%$ of the primary energy demand in 2020 [IEA, 2021b]. The demand for coal in the country is likely to continue to grow in the coming years, but India is also actively developing renewable energy and setting ambitious goals in this area. So, by 2030, India plans to quadruple the installed capacity of renewable energy sources, up to $450 \mathrm{GW}$, including due to the competitiveness of solar energy.

For Russia, the timeline for the transition to climate neutrality has also not yet been determined, and there are no strategic documents necessary for the implementation of such a goal. In 2018, fossil fuel combustion accounted for $79 \%$ of Russia's greenhouse gas emissions excluding land use, land use change, and forestry [UNFCCC, 2020]. Natural gas is the main source of energy consumed in Russia. The share of renewable energy sources in the electric power industry is about $18 \%$, mainly due to hydroelectric power plants, the vast majority of which were built in the USSR. Solar and wind energy are just beginning to develop in the country - in 2020 , only $0.3 \%$ of all electricity was produced from these sources, which is significantly lower than the global average of $9.4 \%$ [Ember, 2021].

\section{Promising areas for low-carbon economic development and international cooperation}

It should be noted that all of the national plans discussed above, as well as the EU plans to achieve carbon neutrality, are schematic and emerging. This means that in the future, they will be refined and modified. Nevertheless, already now, in all the plans of the world's largest economies, the following priorities can be identified.

First, the main task is the decarbonization of the energy sector, which is the largest emitter of greenhouse gases in most countries. The decarbonization of the electric power industry is already proceeding at a fairly fast pace, with heating and transport sectors still lagging behind, especially in such difficult niches in terms of reducing greenhouse gas emissions as aviation, 
shipping and road freight transport. Critical elements of the energy transition also comprise the development of energy storage facilities and new low-carbon energy carriers such as green hydrogen. Special attention is paid to green construction and energy-efficient buildings. Secondly, it is necessary to decarbonize industry on a large scale and reduce the negative environmental impact of the manufacturing sector by introducing the principles of a circular economy, in particular, through the use of renewable raw materials (including the replacement of oil, gas, and coal with such raw materials in chemical processes) and minimizing waste volumes. It is required to transfer industrial processes to renewable energy sources, to reduce the energy intensity and resource intensity of industries. Thirdly, several strategic documents plan to transition to sustainable agriculture, forestry, and fisheries in order to reduce emissions in these sectors, as well as to preserve and restore forests and natural ecosystems that can absorb carbon dioxide from the atmosphere. Some programs for the transition to carbon neutrality pay special attention to R\&D, the development of new low-carbon technologies, and the introduction of innovations.

In the coming decades, these areas will receive the greatest development in the largest economies of the world that are planning a transition to carbon neutrality. Also, these areas, including research, will be especially promising for international cooperation. Through the timely development of low-carbon industries and participation in the creation of new low-carbon technologies, countries that are highly dependent on fossil fuels, including Russia, can reduce the risks of a global transition to net zero emissions, diversify their economies and open up new economic opportunities.

Based on national plans to achieve carbon neutrality, some countries intend to decarbonize the energy sector using nuclear energy, in particular the United States, France, and Japan. That is, they at least do not plan to abandon nuclear energy until 2050. This intention is erroneous because nuclear power plants pose a threat to the environment and public health due to the risk of accidents, the by-product of their operation is hazardous radioactive waste that cannot be recycled or permanently stored, and the costs of generating electricity for new nuclear power plants exceed the costs of generating electricity from both fossil fuels and renewable energy sources [Lazard, 2020]. In addition, the necessity and expediency of the development of nuclear energy are currently being questioned in many significant economies of the world. In particular, Germany has decided to abandon nuclear energy by the end of 2022. In Japan, after the accident at the Fukushima-1 nuclear power plant in 2011, there is a significant resistance to the development of nuclear power from the population and non-profit organizations. Before the accident, $30 \%$ of Japanese electricity was produced at nuclear power plants, and this share was planned to be increased to $40 \%$, but after the accident, in 2012-2015, it decreased to 0-2\%, since all reactors were closed for safety checks. In 2019 , nuclear power plants in Japan produced only $6.4 \%$ of all 
electricity [IEA, 2021f]. There is also strong opposition to the development of nuclear energy in the United States and France. All these factors will significantly limit the development of this industry in the respective countries.

Another misconception is the intention of some countries to develop carbon capture, use and storage technologies (CCUS). These technologies do not solve the problem of environmental pollution, destruction of natural ecosystems through the extraction of natural gas and coal, greenhouse gas emissions during the extraction (in particular, methane emissions) and transportation of fossil fuels. Taking into account greenhouse gas emissions throughout the entire life cycle, CCUS technologies can reduce emissions from electricity generation by only $10.8 \%$ over 20 years of operation of a coal-fired power plant [Jacobson, 2019]. In addition, CCUS technologies stimulate the extraction and combustion of fossil fuels, and the very idea of extracting fossil fuels, combusting them, capturing the carbon emitted and then storing the carbon in order to combat climate change is highly controversial. This idea is even more controversial when considered that electricity generated by coal-fired power plants using CCUS technologies costs 1.5-3 times more than solar and wind power [Lazard, 2020].

\section{The level of development of low-carbon industries in Russia}

In this section, the authors analyze the state of the main low-carbon industries in Russia, such as renewable energy and hydrogen, green buildings, sustainable transport and circular economy in the industrial sector. As it was revealed above, in the coming decades, these industries will flourish in the world. Consequently, these industries have high potential in terms of the development of the Russian economy, and in terms of the implementation of international cooperation and international trade with the participation of Russia. At the same time, it should be noted that the promising areas for the development of the Russian low-carbon economy and international economic cooperation, of course, are not limited to just these four areas, and in addition to them include sustainable agriculture, sustainable forest sector management, household waste management, etc.

\subsection{Renewable energy sources and hydrogen energy}

Renewable energy sources (RES) are sources, "the reserves of which are replenished naturally, primarily due to the flow of solar radiation coming to the Earth's surface, and in the foreseeable future, they are practically inexhaustible" [Popel, 2008]. These sources include solar energy, wind energy, biomass, water flows, and geothermal energy.

Even though the USSR was one of the leaders in the field of renewable energy - in particular, in the field of hydropower and wind energy, in the 2010s, Russia had to start developing renewable energy sources (not counting large hydroelectric power plants that have a negative impact on the environment due to changes in the landscape, flooding of territories, destruction of 
natural ecosystems) practically from scratch. In renewable electric power industry, in the period from 2013 to 2021, a complex system of state support was formed, which now covers all market niches: the wholesale electricity and capacity market (since 2013), retail electricity markets (since 2015), microgeneration (since 2021). There are no state policies to promote renewables in the heating power industry and in the transport sector, although in the heating power industry there has recently been an increase in demand for heat pumps and pellet boilers, due to their economic attractiveness.

Modern utility-scale solar PV and wind power plants (SPP and WPP) began to be built in Russia only after 2015. To date, several dozens of solar power plants and more than 10 wind farms have been built in the country, several modern facilities that manufacture equipment for solar PV and wind energy have been created, such as the production of wind turbine blades in Ulyanovsk, the assembly of nacelles for wind turbines in Dzerzhinsk and in Gorelovo settlement of Leningrad Region, production of towers for wind turbines in Taganrog, production of a generator stator, rotor and main bearing of a wind turbine, generator, hub, and nacelle in Volgodonsk, production of solar panels in Podolsk, production of solar modules and cells in Novocheboksarsk. Transfer of foreign technologies was carried out. Educational programs for personnel training have been created.

However, the development of renewable energy sources is not included in Russia's priorities in the energy sector. The Energy Strategy of Russia for the period up to 2035, adopted in 2020, presupposes the preservation of the traditional directions for the development of the fuel and energy complex for Russia: an increase in the production of natural gas and coal, with the desired preservation of the current volumes of oil production. Renewable energy sources, excluding large hydropower plants, are given an insignificant role in the document and are assigned the only task - to increase the efficiency of energy supply in remote and isolated territories. According to the existing official plans for renewable energy, by 2025, the installed capacity of solar PV, wind, and small hydropower plants will reach about $2.5 \%$ of the total installed capacity, and the share of these sources in electricity production will comprise about $1 \%$. By 2035 , these values may grow to $5.4 \%$ and $2.3 \%$, respectively [Lanshina, 2021]. In 2020, $9.4 \%$ of the global electricity was produced only using solar PV and wind energy. Russia is one of the three G20 countries, along with Saudi Arabia and Indonesia, whose share of solar PV and wind energy in the electric power production is still close to zero [Ember, 2021].

Unlike renewable energy sources, hydrogen energy has recently received a lot of attention in Russia, including within the framework of the updated Energy Strategy, where it is viewed as a promising direction, including for exports. The Energy Strategy sets a goal to increase the export of hydrogen to 0.2 million tons by 2024 and 2 million tons by 2035 . However, the document mainly envisions hydrogen produced from fossil fuels or using nuclear power, while globally, the 
main attention is now paid to the development of green hydrogen, produced by water electrolysis using electricity from renewable energy sources. Hydrogen from water electrolysis using nuclear energy is already being actively pursued by the state corporation Rosatom. Rosatom is entrusted with the planning and implementation of pilot projects for the production of hydrogen using nuclear energy in Russia and abroad, the development of our own technologies for the production, storage, and transportation of hydrogen, and the formation of long-term strategic and technological partnerships in this area. The industry integrator of this direction is JSC Rusatom Overseas, whose goal is to expand the foreign portfolio of orders of state corporation Rosatom enterprises and to maintain Russia's leading position in the global nuclear market.

Thus, Russia already has some competencies in the production of equipment for solar PV and wind energy, as well as experience in the construction and operation of solar PV and wind power plants. However, this experience is still insignificant and requires further development in terms of deepening the localization of production operations, replacing outdated thermal power plants with modern SPPs and WPPs, construction of new renewable energy power plants for the production of green hydrogen, development of green hydrogen production, formation of state policies aimed at stimulating the integration of RES in the heating and cooling sector and in the transport sector.

\subsection{Green buildings}

Green buildings are defined as buildings that through their design, construction or operation reduce or eliminate negative impacts and have a positive impact on the climate and the environment [WGBC, 2021]. There are several international green building standards such as BREEAM (Building Research Establishment's Environmental Assessment Method), LEED (Leadership in Energy and Environmental Design), DGNB (German Sustainable Building Council), which assess the environmental and energy efficiency of buildings design.

In Russia, the green building sector is still at the initial stage of development. As of May 2021, the number of certified buildings in the country amounted to only 211 units, of which $46 \%$ are offices, $23 \%$ are retail real estate, $15 \%$ are warehouse and industrial facilities, and the remaining $16 \%$ are distributed among other types of buildings [Knight Frank, 2021]. For comparison, in the UK, the number of certified green buildings is about 19,000, in the United States - about 138,000 [GBIG, 2021]. However, in Russia, the usual technologies of energy saving are actively deployed, such as LED lamps and motion sensors, thermal insulation of windows and doors and temperature control. Among the reasons for such a slow development of the green construction industry in Russia is the low cost of energy in Russia, the lack of significant financial incentives for this industry from the state, the lack of understanding of the importance of introducing green standards, as well as the long payback period of such projects, especially with 
the use of environmentally friendly building materials, which is a key risk in the Russian unstable macroeconomic environment [Korol, 2017].

Russia has significant potential for the further introduction of energy and heat saving technologies, the introduction of environmentally friendly building materials, as well as the certification of buildings in accordance with international green building standards.

\subsection{Eco-friendly vehicles}

Eco-friendly or sustainable transport is transport that minimizes the negative impact on the environment without compromising the efficiency of the transport system. At the moment, environmentally-friendly vehicles include cars, trucks, passenger cars, and buses operating on alternative energy sources: electricity, hydrogen, biogas.

In Russia, environmentally-friendly vehicles are gaining popularity. For example, from September 1, 2018, within the framework of the Energy of Moscow project, the first Moscow electric buses began operating; by 2030, state unitary enterprise Mosgortrans plans to completely switch to electric buses. However, successes in the electrification of vehicles are noticeable only in the field of passenger transport and only in Moscow, where in 2020 electric buses accounted for $7.1 \%$ (or 600 units) of the total vehicle fleet of passenger buses. In addition, in Moscow, trolleybuses were replaced by electric buses, which is not entirely logical, since the trolleybus represents environmentally friendly transport. Within the framework of the State Program of the city of Moscow "The Development of the Transport System", it is planned to increase the share of electric buses to $14.4 \%$ by 2021 , and to $23 \%$ by 2022 . By 2030 , the city plans to fully switch from fossil-fueled buses to electric buses.

In other cities of Russia, the transition to electric buses is not a popular trend in the field of transport policy due to their high cost and the need to create charging infrastructure. In St. Petersburg, in 2018, the state unitary enterprise Passazhiravtotrans purchased several electric buses that operate on the only route number 28. The company is actively developing vehicles using compressed natural gas (methane), and the fleet of buses running on natural gas comprises 163 units. Another St. Petersburg carrier, Gorelectrotrans, from 2017 to 2020, launched 9 electric bus routes with dynamic charging, which in fact represent modernized trolleybuses, since they depend on the overhead electric network. In 2020, one test route of an electric bus was launched in Samara, but it was suspended a year later. In Naberezhnye Chelny, 3 electric buses are operated for employees of the research and development center of KAMAZ. Instead of electric buses, Russian regions are developing tram and trolleybus networks, which are less expensive.

The number of electric vehicles in Russia is extremely low. As of January 1, 2021, 10,800 electric vehicles were registered in Russia [Avtostat, 2021], which is $71 \%$ higher than in 2020. For comparison, in the United States in 2019, more than 800,000 electric cars and about 570,000 hybrid 
cars were registered. China, which is the leader in the electric car fleet, registered 2,600,000 electric vehicles and 770,000 hybrid vehicles in 2019. There are 970,000 electric vehicles and 780,000 hybrid vehicles in the EU [IEA, 2020].

To stimulate the demand for electric vehicles, it is necessary to create a modern and extensive infrastructure of charging stations. In Russia, according to various estimates, the number of operating charging stations is about 450 units [Kommersant, 2021]. This is not enough even for the existing number of electric cars, since there should be at least one charging station for 10 electric vehicles, that is, there should be at least 1,000 of working stations in Russia. In addition, in Russia there is no single system of charging stations and no single requirements for power and type of connection. For this reason, it is difficult to assess their real number and capacity, as well as the fact that these stations are connected to the network.

The Ministry of Economic Development of Russia plans to build 20,000 charging stations by 2024 and 150,000 - by 2030. In particular, this is due to import substitution plans, since from 2024, it is planned to limit imports of the production of electric vehicles by introducing additional tax levies and stimulating the production of a Russian electric vehicle based on KamAZ [RBC, 2021]. KamAZ is the only Russian automaker with a working prototype of an electric vehicle.

Thus, the electrification of personal and passenger vehicles in Russia is at an early stage of development. The number of electric vehicles and charging stations is small and insufficient to mark a significant development in the industry. In the electrification of passenger transport, Moscow is noticeably leading with a share of electric buses of $7.1 \%$; other Russian cities do not plan to introduce this technology on a large scale due to its high cost and the need to develop the corresponding infrastructure.

Russia needs to create a unified network of electric charging stations, to significantly increase the number of such stations, as well as to introduce policies aimed at the supply of renewable electricity for charging electric vehicles, to develop the production of Russian electric vehicles, as well as to stimulate the transition from internal combustion engines to electric motors, for example, through a ban on the sale of new vehicles with internal combustion engines from a certain year, following the example of the EU.

\subsection{Circular economy and green technologies in the industrial sector}

A circular economy is defined as an economic system aimed at achieving zero waste and zero emissions throughout the entire life cycle of a product, including the extraction of raw materials, industrial processing, consumption, and disposal of waste [Nobre \& Tavares, 2021]. The essence of the concept of a circular economy is the introduction of value on products, materials and waste, in contrast to the traditional linear economic model based on the "take-produce- 
consume-throw away" scheme, and its main principle is to achieve maximum efficiency in the manufacturing of products and waste recycling in order to limit the leakage of resources.

In Russia, the introduction of a ciruclar economy in the industrial sector is at the theoretical stage and is not a modern trend. There are several isolated examples of Russian initiatives in this area, such as the GreenTire project in the Green Moscow cluster. Within the framework of the project, it is planned to create a service and production complex of a full cycle for the operation, an extension of the service life, and the reuse of large-sized tires. The leaders and pioneers in the implementation of circular economy models in production are the Russian offices of transnational corporations. IKEA in Russia has followed the resource recovery model and launched several ongoing projects to recycle and reuse chipboard, cardboard, cardboard corners, paper cups, and stretch film. The company says it currently recycles $77 \%$ of waste generated in its stores and has an ambitious target of $100 \%$ by 2030 [IKEA, 2021]. It should be noted that the above examples are solely the initiative of companies since in Russia environmental legislation obliges companies not to recycle, but to process, dispose and neutralize production waste. In the EU countries, for example, the main beneficiary in the transition to a circular economy is the state, which introduces strict standards for industrial and manufacturing enterprises in the management of industrial waste.

If the introduction of a circular economy in the industry is a systemic and long-term process, then another related area of greening production - the introduction of green technologies - is more accessible to Russian companies. Green technologies are defined in several sources as technologies and methods that help to reduce a negative impact on the environment by emitting fewer harmful substances, removing such substances from emissions before dumping, or through the disposal and recycling of industrial residues [UN, 1997; OECD, 1999]. These technologies include increasing energy efficiency at an enterprise, reducing fuel losses through the introduction of appropriate technologies, recycling waste, replacing fossil fuels with renewable energy sources, and others.

Among the largest Russian oil and gas and industrial enterprises, the following priorities in the implementation of green technologies can be identified: increasing the energy efficiency of enterprises and reducing energy consumption (Gazpromneft, Rosneft, Lukoil, GAZ Group, Metalloinvest), modernization of production equipment. Green technologies introduced in metallurgy comprise direct iron reduction and steel smelting in electric furnaces (Metalloinvest), greener electrolytic cell technology (RUSAL), and transition to dry gas cleaning units (RUSAL). In the chemical industry, the following green technologies are being introduced in Russia: a complex for deep processing of hydrocarbons into polyolefins (polymers) (ZapSibNeftekhim plant of SIBUR), production of polyester polyols based on recycled carbon dioxide (Covestro). The 
listed technologies are aimed at reducing greenhouse and harmful gas emissions in the metallurgical and chemical industries. It should be noted that they are mainly implemented by the largest Russian exporters in order not to lose access to international markets and comply with the legislation of the importing countries.

The introduction of the best available technologies (BAT) can make a significant contribution to the greening and decarbonization of the industrial sector. In Russia, in the past few years, large-scale work has been carried out on the transition to BAT - in particular, in 2014 amendments to the Federal Law "On Environmental Protection" were adopted to determine the legal basis for state policy in the field of BAT, 51 sectoral and inter-sectoral BAT reference books were developed taking into account Russian and international experience, the federal project "Implementation of the best available technologies" is being implemented within the framework of the national project "Ecology". In accordance with the updated Law on Environmental Protection, BAT should have the lowest level of environmental impact per unit of time or volume of products produced, be cost-effective, use resource and energy conservation methods, and be applied on an industrial scale for two or more objects in Russia. The purpose of BAT implementation is to reject outdated and ineffective technologies and replace them with more advanced and environmentally friendly analogs. However, while work on the transition to BAT in Russia is not transparent enough, industrial companies exert too much influence on it, and there is no strategy for the implementation of BAT.

Thus, in Russia, there is no single trend for the transition to a circular economy and the introduction of green technologies in the industrial sector. The leaders in the transition to a new green economy are either Russian branches of large transnational corporations, which use operating models already established in other countries, or the largest Russian industrial exporting companies, which are forced to introduce green technologies to maintain their positions in international trade. At the same time, since the circular economy is still an emerging technology cluster all over the world, Russia has the opportunity to take a leading position in this sphere, subject to timely (immediate) active involvement in $\mathrm{R} \& \mathrm{D}$, as well as in the process of commercialization of relevant technologies.

\section{Conclusion}

The priority of all the strategic documents discussed in this article regarding the achievement of carbon neutrality by the world's largest economies by the middle of the century is the energy transition, which consists of the most ambitious development of renewable energy sources in all energy sectors (electricity, heating and cooling, transport), increasing energy efficiency and reducing the volume of fossil fuels use, especially coal, since fossil fuels combustion is the main source of greenhouse gas emissions in most countries. Also, important 
attention in all programs is paid to the reduction of emissions in the industrial sector (the introduction of circular economy principles, which implies a reduction in waste generation, waste recycling, and the replacement of coal with green hydrogen or other green energy sources in industrial processes), as well as in the agricultural and forestry sectors, through the introduction of the principles of organic farming and sustainable forest management. It is these technologies and industries that will grow rapidly in the near future.

Some countries erroneously plan to decarbonize the energy sector using nuclear power and carbon capture, use and storage (CCUS) technologies. These technologies are too expensive and dangerous for the environment, life, and health of the population. In addition, some major economies are planning to phase out nuclear power, e.g. Germany will close all nuclear reactors by the end of 2022. In other countries, such as Japan, the United States, and France, there is significant resistance to the development of nuclear energy from the population and non-profit organizations, which will also limit the development of this industry. Despite these shortcomings, all of the world's leading economies that have set themselves the goal of carbon neutrality and developed corresponding strategic documents will face a large-scale low-carbon transformation in the coming decades, which will reshape existing production technologies, supply chains, and product life cycles. This will inevitably have a negative impact on the Russian economy, which is highly dependent on the supply of carbon-intensive products to other countries.

To reduce the negative impact of the global transition to carbon neutrality on the Russian economy, Russia should pay close attention to the development of those technologies that will be most in demand in the world in the coming years. As it was revealed in this article, in Russia these technologies, in particular, RES, green hydrogen, green construction, environmentally-friendly vehicles, elements of a circular economy in industrial sector, are at the initial stage of development, and many of them, including the key low-carbon technologies such as renewable energy, have received little attention to date. Thus, modern renewable energy technologies have been developing in Russia only since 2015 and provide an insignificant contribution - for example, the share of wind and solar energy in electricity production is only $0.3 \%$, while in the world every tenth kilowatt-hour is produced from these sources. The number of certified green buildings in Russia is in the hundreds, while in other large economies of the world - tens of thousands. Electric transport has received significant development only in Moscow and only in the electric bus sector, and partly due to the displacement of trolleybuses, while in general, the country has an extremely low level of development of charging infrastructure. There are few examples of the introduction of the principles of a circular economy in industry, some companies, mainly the largest exporters, are introducing more affordable green technologies, but this practice is also not sufficiently targeted and widespread. 
Accelerated development of the listed technologies and industries and ensuring international cooperation in them, including cooperation in the field of $R \& D$, transfer of foreign technologies, development of Russian technologies and high-tech products both for supplying the domestic market and for export supplies, can bring benefits to the Russian economy, protect it from the risk of a decrease in global demand for fossil fuels, contribute to its diversification, facilitate its recovery from the crisis after the pandemic and ensure Russia high rates of economic growth in the long term. In particular, Russia needs to deepen the localization of the production of equipment for renewable energy sources, gradually replace the outdated capacity of thermal power plants with modern solar power plants and wind farms, build new renewable energy plants for the production of green hydrogen, master the production of green hydrogen, formulate a state policy aimed at stimulating the implementation of RES in the thermal energy sector and in the transport sector, introduce energy and heat saving technologies, stimulate the use of environmentally friendly building materials, as well as certification of buildings in accordance with international green building standards, create a unified network of electric charging stations, significantly increase the number of such stations, pursue a policy aimed at supplies of renewable electricity for charging electric vehicles, develop the production of Russian electric vehicles, stimulate the transition from internal combustion engines to electric motors (for example, through a ban on the sale of new cars with internal combustion engines from a certain year, following the example of the EU), introduce the best available technologies, develop green technologies and introduce the principles of a circular economy in industrial sector. 


\section{References}

Autostat (2021). The number of electric vehicles in Russia has exceeded 10 thousand units. Available at: https://www.autostat.ru/news/47243/ (accessed 1 July 2021).

Kommersant (2021). Get ready to charge. Available at: https://www.kommersant.ru/doc/4816869 (accessed 1 July 2021).

Korol T.O. (2017). The role of natural and environmental factors in the implementation of green building technologies in Russia // RUDN Journal of Ecology and Life Safety. 2017. №1. Available at: https://cyberleninka.ru/article/n/rol-prirodno-ekologicheskih-faktorov-privnedrenii-zelenyh-stroitelnyh-tehnologiy-v-rossii (accessed 3 July 2021).

Lanshina T. (2021). Russia's wind energy market: potential for new economy development. Available at: https://www.fes-russia.org/fileadmin/user_upload/documents/210316FESMOS-windenergy-ru.pdf?fbclid=IwAR3jqNAltsIkuSzGRk-

TmkUZTmIb7SBvyBiUfE4OENtgoMOECmlOzoeDZ24 (accessed 11 July 2021).

IPCC (2019). Global Warming of $1.5{ }^{\circ} \mathrm{C}$. Available at: https://www.ipcc.ch/site/assets/uploads/sites/2/2019/09/IPCC-Special-Report-1.5-SPM_ru.pdf (accessed 30 July 2021).

Popel O. S. (2008). Renewable energy sources: role and place in modern and future energy system // Russian Chemical Journal, №52 (6), pp. 95-106. Available at: http://chem.msu.ru/rus/jvho/2008-6/95.pdf (accessed 23 July 2021).

RBC (2021). Ministry of economic development plans to develop electric transport for P418 billion.

Available at: https://www.rbc.ru/economics/18/05/2021/60a2eea79a794792e1387b24 (accessed 1 July 2021).

Bundesamt für Justiz (2019). Bundes-Klimaschutzgesetz (KSG). Available at: https://www.gesetze-im-internet.de/ksg/BJNR251310019.html (accessed 17 July 2021). Available

Bundesministerium der Finanzen (2021). Sofortprogramm für mehr Klimaschutz. https://www.bundesfinanzministerium.de/Content/DE/Standardartikel/Themen/Schlaglichter/Kli maschutz/klimaschutz-sofortprogramm.html (accessed 11 July 2021).

Bundesregierung (2019). Climate Action Programme 2030. Available at: https://www.bundesregierung.de/breg-en/issues/climate-action/klimaschutzprogramm-20301674080 (accessed 21 July 2021).

Bundesregierung (2021a). Generationenvertrag für das Klima. Available at: https://www.bundesregierung.de/breg-de/themen/klimaschutz/klimaschutzgesetz-2021-1913672 (accessed 12 July 2021).

Bundesverfassungsgericht (2021). Constitutional complaints against the Federal Climate Change Act partially successful. Available at: https://www.bundesverfassungsgericht.de/SharedDocs/Pressemitteilungen/EN/2021/bvg21031.html (accessed 11 July 2021).

C2ES (2019). Global Emissions. Available at: https://www.c2es.org/content/internationalemissions/ (accessed 11 July 2021).

Chen J.M. (2021). Carbon neutrality: Toward a sustainable future // The Innovation, V. 2(3). Available at: https://doi.org/10.1016/j.xinn.2021.100127 (accessed 13 July 2021).

Climate Action Tracker (2020). Brazil. Available

at: https://climateactiontracker.org/countries/brazil/ (accessed 30 June 2021).

Climate Home News (2021). UK calls on Indonesia to set out roadmap to net zero emissions. Available at: https://www.climatechangenews.com/2021/06/03/uk-calls-indonesia-setroadmap-net-zero-emissions/ (accessed 9 July 2021).

Climate Transparency (2020). Brazil. Available at: https://www.climatetransparency.org/wp-content/uploads/2020/11/Brazil-CT-2020-WEB2.pdf (accessed 30 June 2021). 
Ember (2021). Global Electricity Review. Available at: https://emberclimate.org/project/global-electricity-review-2021/ (accessed 12 June 2021).

Energy\&Climate Intelligence Unit (2021a). Net zero emissions race. Available at: https://eciu.net/netzerotracker (accessed 11 July 2021).

Energy\&Climate Intelligence Unit (2021b). Taking stock: a global assessment of net zero targets. Available at: https://ca1-eci.edcdn.com/reports/ECIUOxford_Taking_Stock.pdf?mtime=20210323005817\&focal=none (accessed 17 July 2021).

European Commission (2019). Communication from the Commission. The European Green Deal. Available at: https://eur-lex.europa.eu/legalcontent/EN/TXT/?qid=1576150542719\&uri=COM\%3A2019\%3A640\%3AFIN (accessed 15 July 2021).

European Commission (2021). Delivering the European Green Deal. Available at: https://ec.europa.eu/info/strategy/priorities-2019-2024/european-green-deal/delivering-europeangreen-deal_en (accessed 11 July 2021).

European Council (2020). European Council meeting (10 and 11 December 2020) conclusions. Available at: https://www.consilium.europa.eu/media/47296/1011-12-20-eucoconclusions-en.pdf (accessed 15 July 2021).

European Council (2021). Council adopts European climate law. Available at: https://www.consilium.europa.eu/en/press/press-releases/2021/06/28/council-adopts-europeanclimate-law/ (accessed 9 July 2021).

European Parliament (2018). International Climate Negotiations. Issues at stake in view of the COP 24 UN Climate Change Conference in Katowice and beyond. Available at: https://www.europarl.europa.eu/RegData/etudes/STUD/2018/626092/IPOL_STU(2018)626092_ EN.pdf (accessed 11 July 2021).

Eurostat (2021). CO2 emissions from energy use clearly decreased in the EU in 2020. Available at: https://ec.europa.eu/eurostat/web/products-eurostat-news/-/ddn-20210507-1 (accessed 11 July 2021).

FMPRC (2020). Statement by H.E. Xi Jinping President of the People's Republic of China At the General Debate of the 75th Session of The United Nations General Assembly. Available at: https://www.fmprc.gov.cn/mfa_eng/zxxx_662805/t1817098.shtml (accessed 5 July 2021).

Fraunhofer (2021). Public Net Electricity Generation in Germany 2020: Share from Renewables Exceeds 50 percent. Available at: https://www.ise.fraunhofer.de/en/pressmedia/news/2020/public-net-electricity-generation-in-germany-2020-share-from-renewablesexceeds-50-percent.html (accessed 11 July 2021). 2021).

GBIG (2021). Places. Available at: http://www.gbig.org/places/468 (accessed 2 July

IEA (2020). Global EV Outlook 2020, IEA, Paris. Available at: https://www.iea.org/reports/global-ev-outlook-2020 (accessed 1 July 2021).

IEA (2021a). Country profile. France. Available at: https://www.iea.org/countries/france (accessed 9 July 2021).

IEA (2021b). Country profile. India. Available at: https://www.iea.org/reports/indiaenergy-outlook-2021 (accessed 9 July 2021).

IEA (2021c). Country profile. Brazil. Available at: https://www.iea.org/countries/brazil (accessed 9 July 2021).

IEA (2021d). Country profile. Indonesia. Available at: https://www.iea.org/countries/indonesia (accessed 11 July 2021).

IEA (2021e). Country profile. China. Available at: https://www.iea.org/countries/china (accessed 9 July 2021). 
IEA (2021f). Country profile. Japan. Available at: https://www.iea.org/countries/japan (accessed 9 July 2021).

IKEA (2021). Циклическая экономика. Available at: https://www.ikea.com/ru/ru/this-isikea/sustainable-everyday/ciklicheskaya-ekonomika-pub70ec0220 (accessed 11 July 2021).

Iqbal N., Abbasi K.R., Shinwari R., Guangcai W., Ahmad M., Tang K. (2021). Does exports diversification and environmental innovation achieve carbon neutrality target of OECD economies? // Journal of Environmental Management, V. 291. Available at: https://doi.org/10.1016/j.jenvman.2021.112648 (accessed 1 August 2021).

Jacobson M. Z. (2019). The health and climate impacts of carbon capture and direct air capture // Energy\&Environmental Science, V. 12, pp. 3567-3574. Available at: https://web.stanford.edu/group/efmh/jacobson/Articles/Others/19-CCS-DAC.pdf. (accessed 18 September 2021).

Joe Biden (2020). The Biden plan for a clean energy revolution and environmental justice. Available at: https://joebiden.com/climate-plan/ (accessed 17 July 2021).

Joe Biden (2021). The Biden plan to build a modern, sustainable infrastructure and an equitable clean energy future. Available at: https://joebiden.com/clean-energy/ (accessed $11 \mathrm{July}$ 2021).

Knight Frank (2021). 37\% компаний по всему миру планируют увеличить долю «зеленых» офисов в своем портфеле недвижимости. Available at: https://kf.expert/news/37kompanij-po-vsemu-miru-planiruyut-uvelichit-dolyu-zelenyh-ofisov-v-svoem-portfelenedvizhimosti (accessed 2 July 2021).

Lazard (2020). Lazard's levelized cost of energy analysis - Version 14.0. Available at: https://www.lazard.com/media/451419/lazards-levelized-cost-of-energy-version-140.pdf (accessed 29 July 2021).

Legifrance (2019). LOI n 2019-1147 du 8 novembre 2019 relative à l'énergie et au climat. Available at: https://perma.cc/5XYM-8VDA (accessed 15 July 2021).

Li Y., Lan S., Ryberg M., Perez-Ramirez J., Wang X. (2021). A quantitative roadmap for China towards carbon neutrality in 2060 using methanol and ammonia as energy carrier // iScience, V. 24. Available at: https://doi.org/10.1016/j.isci.2021.102513 (accessed 11 July 2021).

METI (2020). Green Growth Strategy Through Achieving Carbon Neutrality. Available at: https://www.meti.go.jp/english/press/2020/1225_001.html (accessed 29 June 2021).

MIC (2021). Act on Promotion of Global Warming Countermeasures. Available at: https://elaws.e-gov.go.jp/document?lawid=410AC0000000117 (accessed 16 July 2021).

Ministere de la Transition Ecologique (2020). National Low Carbon Strategy. Available at: https://unfccc.int/sites/default/files/resource/en_SNBC-2_summary_4-pages.pdf (accessed 9 July 2021).

Nakano J. (2020). Japan Seeks Carbon Neutrality by 2050 // CSIS. Available at: https://www.csis.org/analysis/japan-seeks-carbon-neutrality-2050 (accessed 30 June 2021).

Nobre G.C., Tavares E. (2021). The quest for a circular economy final definition: A scientific perspective // Journal of Cleaner Production, Volume 314. Available at: https://doi.org/10.1016/j.jclepro.2021.127973 (accessed 11 July 2021).

OECD (1999). The Environmental Goods and Services Industry // OECD, Eurostat. - P. 9.

Reuters (2021a). China to cut coal use share below 56\% in 2021. Available at: https://www.reuters.com/world/china/china-cut-coal-use-share-below-56-2021-2021-04-22/ (accessed 11 July 2021).

Reuters (2021b). Brazil's Bolsonaro, under U.S. pressure, vows climate neutrality by 2050. Available at: https://www.reuters.com/business/environment/bolsonaro-says-brazil-will-reachclimate-neutrality-by-2050-2021-04-22/ (accessed 11 July 2021).

Safi A., Chen Y., Wahab S., Zheng L., Rjoub H. (2021). Does environmental taxes achieve the carbon neutrality target of G7 economies? Evaluating the importance of environmental R\&D 
// Journal of Environmental Management, V. 293. Available at: https://doi.org/10.1016/j.jenvman.2021.112908 (accessed 1 August 2021).

Stern N., Valero A. (2021). Innovation, growth and the transition to net-zero emissions // Research Policy. V. 50. Available at: https://doi.org/10.1016/j.respol.2021.104293 (accessed 11 July 2021).

The White House (2021). Executive Order on Tackling the Climate Crisis at Home and Abroad. Available at: https://www.whitehouse.gov/briefing-room/presidentialactions/2021/01/27/executive-order-on-tackling-the-climate-crisis-at-home-and-abroad/ (accessed 9 July 2021).

UK Government (2021). The Ten Point Plan for a Green Industrial Revolution. Available at:

https://assets.publishing.service.gov.uk/government/uploads/system/uploads/attachment_data/fil e/936567/10 POINT PLAN_BOOKLET.pdf (accessed 11 July 2021).

UK Legislation (2019). The Climate Change Act 2008 (2050 Target Amendment) Order 2019. Available at: https://www.legislation.gov.uk/uksi/2019/1056/contents/made (accessed 11 July 2021). York.

UN (1997). Glossary of Environment Statistics, Studies in Methods, Series F, No. 67, New

UNFCCC (2020). Russian Federation. 2020 National Inventory Report (NIR). Available at: https://unfccc.int/documents/226417 (accessed 12 July 2021).

Wan B., Tian L., Fu M., Zhang G. (2021). Green development growth momentum under carbon neutrality scenario // Journal of Cleaner Production, V. 316. Available at: https://doi.org/10.1016/i.jclepro.2021.128327 (accessed 23 July 2021).

WGBC (2021). About green building. Available at: https://www.worldgbc.org/whatgreen-building (accessed 2 July 2021).

World Bank (2021). Gross domestic product 2020, PPP. Available at: https://databank.worldbank.org/data/download/GDP_PPP.pdf (accessed 16 July 2021). 